\title{
Anfis Based Material Flow Rate Control System for Weigh Feeder Conveyor
}

\author{
Dibaj Al Rosyada ${ }^{1}$, Misbah $^{1} \&$ Eliyani ${ }^{1}$ \\ ${ }^{1}$ Electrical Engineering Program, Faculty of Engineering, Universitas Muhammadiyah Gresik, Indonesia \\ Correspondence: Misbah, Electrical Engineering Program, Faculty of Engineering, Universitas Muhammadiyah \\ Gresik. Jl. Sumatera 101 GKB, Gresik, 61121, Indonesia. Tel: 62-81-5501-7329. E-mail: misbah@umg.ac.id
}

Received: April 6, 2016

Accepted: April 16, 2016

Online Published: May 2, 2016

doi:10.5539/cis.v9n2p112

URL: http://dx.doi.org/10.5539/cis.v9n2p112

\begin{abstract}
Weight control system on the feeder conveyor determines the factor of the quality of products within an industry. The dynamics of the flow rate of material through the feeder conveyor weigh requires a good level of performance controllers. The base of current controllers such as FLC (Fuzzy Logic Controller) requires a certain amount of knowledge and expertise in its design that will make it difficult to achieve good system performance. These difficulties can be overcome by using systems based on ANFIS (Adaptive Neuro-Fuzzy Inference System). By doing the learning offline, using ANFIS can be obtained by fuzzy inference systems to create a controller FLC. Microcontroller have FLC controller program, its integrated with notebook can monitor and control the notebook weigh feeder conveyor system. Designing a system that has been created will give good results with an average error value of $3.86 \%$ at the set-point of 1000 grams / minute, and the average error of $5.03 \%$ on set-point 2000 grams / minute in ten times testing.
\end{abstract}

Keywords: ANFIS, weigh feeder conveyor, a microcontroller

\section{Introduction}

Weigh feeder conveyor control principle is to maintain the desired flow rate by adjusting the conveyor belt speed in proportion to the weigh of the material. The dynamics of the rate of material through the conveyor weigh feeder demanding good performance level controllers. Lack of optimal performance in weigh feeder conveyor controller base can cause product failure and loss.

Base controllers used in weight feeder conveyor is still using conventional technique PID (Proportional Integral Derivative). In general, conventional PID controllers have been successfully used for various processes, but there are still some limitations, its performance is highly dependent on the operational parameters of the plant (Nazarudin, 2009). To further improve the process of control may use other alternative techniques to produce better system response (Saputro, 2007).

The difficulty in designing a modern controller such as FLC (Fuzzy Logic Controller) can be overcome by using systems based on neuro fuzzy. The main advantage in neuro fuzzy systems is the learning capabilities of the data - numerical data is obtained from the measurements, so it does not require a mathematical model of the process to be controlled (Nazarudin, 2009).

Design of fuzzy inference systems on Sugeno method is designed in this study to address the dynamics of the process of controlling the conveyor weigh feeder. Learning off - line using ANFIS is done by the help of Matlab R2011b software.

\section{Literature Review}

\subsection{Fuzzy Set Theory}

Fuzzy set is a generalization of the concept of a regular set. For the universe of discourse X, fuzzy set is defined by the membership function which maps $X$ members to membership degree $\mu(x)$ in the interval $\{0,1\}$ is shown in Figure 2.1 (Widodo, 2005). 


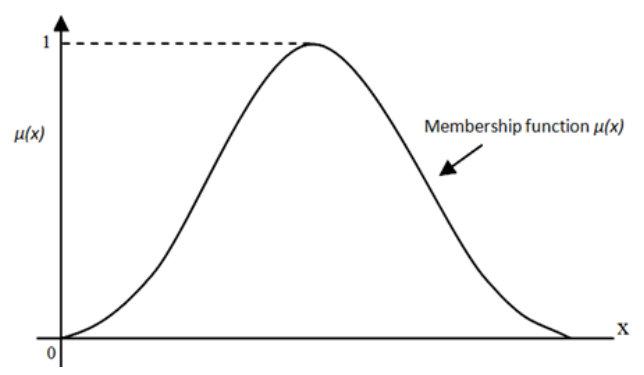

Figure 2.1. Membership Function of a Fuzzy Set

\subsection{Fuzzy Inference System}

Fuzzy Inference System (FIS) is a computational framework that is based on fuzzy set theory, fuzzy rules in the form of IF - THEN, and fuzzy reasoning. Broadly speaking, fuzzy inference process block diagram is shown in Figure 2.2 (Kusumadewi, 2006).

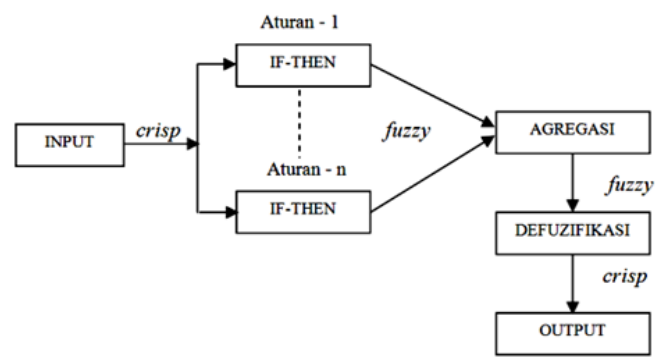

Figure 2.2. Fuzzy Inference System

\subsection{Fuzzy Logic Controller (FLC)}

FLC can be combined with close loop system as shown in Figure 2.3.

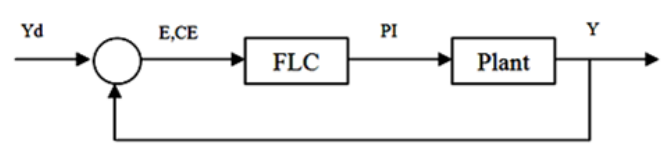

Figure 2.3. FLC Structure

Plant output desired by the reference value (Yd) compared to actual output (Y), so that there is an error (Error, E). Error (E) and the change of the error (Change of error, CE) is a variable input for FLC. FLC output is the input of plant or input process (Process Input, PI) (Widodo, 2005)..

\subsection{Adaptive Neuro Fuzzy Inference System}

ANFIS (Adaptive Neuro Fuzzy Inference System or Adaptive Network-based Fuzzy Inference System) is an architecture that is functionally similar to the fuzzy rule base by Sugeno models is shown in Figure 2.4. ANFIS architecture is similar to the function of the radial nerve tissue with minimal limitations. ANFIS allows rules to adapt (Kusumadewi, 2006). 


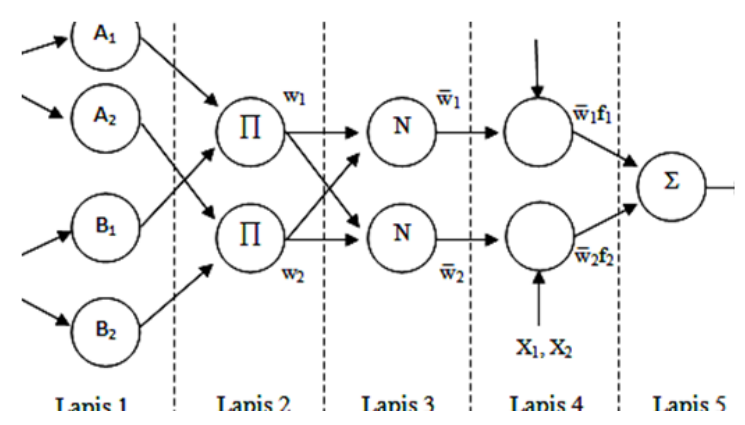

Figure 2.4. ANFIS Architecture

\subsection{Weigh Feeder Conveyor}

Weight feeder conveyor is used to move the material to the rotation of the motor as the main driver connected with the drum / pulley shrouded by a belt is shown in Figure 2.5. To measure the weight of the material, this object using a weight sensor load cell, whereas to measure the speed of the belt, we are using a tachometer.

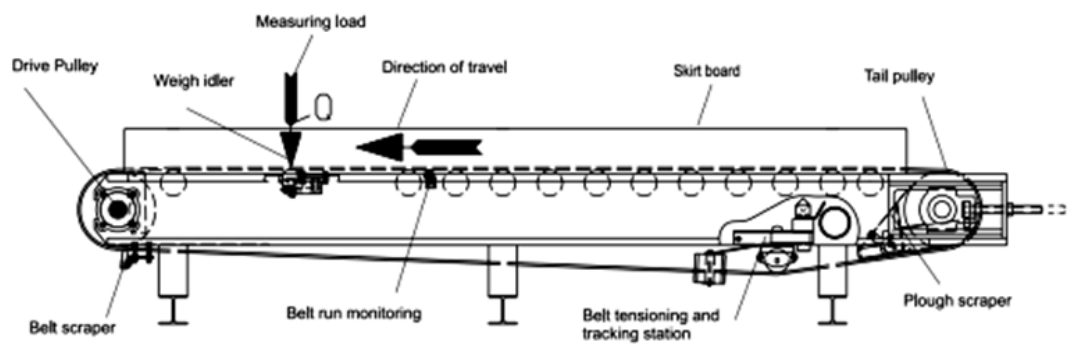

Figure 2.5. Weigh feeder conveyor

\section{Designing Tools}

Weight feeder conveyor system is shown in Figure 3.1.

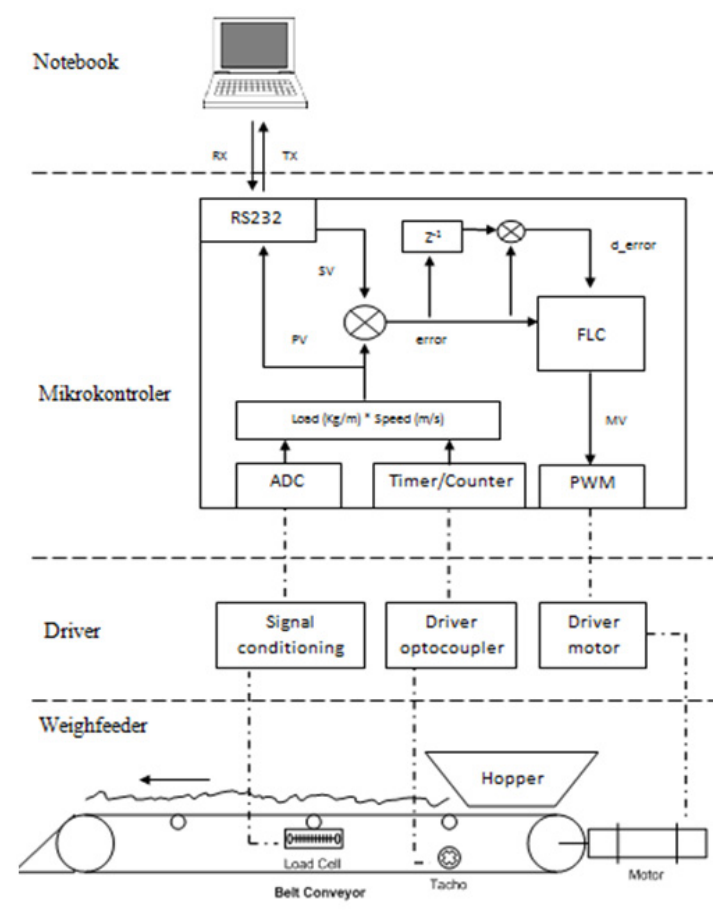

Figure 3.1. System diagram 


\subsection{AT Mega16 Minimum System}

In this section ATmega16 microcontroller mounted with some supporting components so that the cycle of controllers can work continuously. ATMega 16 Minimum system scheme can be seen in Figure 3.2

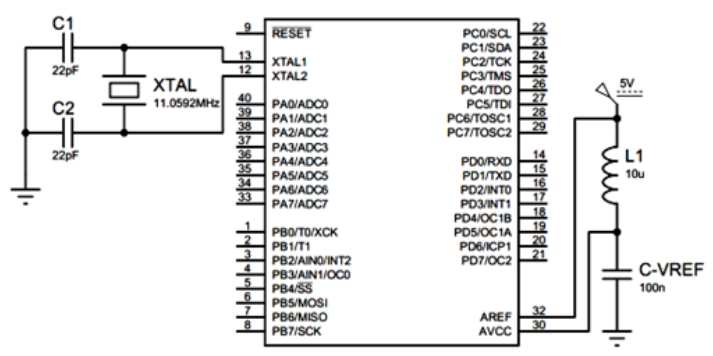

Figure 3.2. ATmega16 Minimum system

\subsection{Load Cell}

The maximum capacity load cell used is $10 \mathrm{~kg}$ with rate the characteristics of a voltage of $2 \mathrm{mV} / \mathrm{V}$. If the supply voltage of the load cell is given $20 \mathrm{~V}$, then the maximum load conditions the load cell output voltage is $40 \mathrm{mV}$. In Table 3.1 it can be seen the results of calculations between the load and the load cell output voltage with an excitation voltage of $20 \mathrm{~V}$.

Table 3.1. Calculation of load cell output

\begin{tabular}{ll}
\hline Load $(\mathrm{kg})$ & Output $(\mathrm{mV})$ \\
\hline 0 & 0 \\
1 & 4 \\
2 & 8 \\
3 & 12 \\
4 & 16 \\
5 & 20 \\
6 & 24 \\
7 & 28 \\
8 & 32 \\
9 & 36 \\
10 & 40 \\
\hline
\end{tabular}

\subsection{Signal Conditioning}

Load cell output voltage is still too small which boosted further on signal conditioning circuit. Signal conditioning circuit serves as an amplifier output signal which is generated by loadcell.

Table 3.2. Calculation of output signal conditioners (gain $=125$ )

\begin{tabular}{lll}
\hline Load $(\mathrm{kg})$ & Loadcell $(\mathrm{mV})$ & Instrument Amplifier (V) \\
\hline 0 & 0 & 0 \\
1 & 4 & 0,5 \\
2 & 8 & 1 \\
3 & 12 & 1,5 \\
4 & 16 & 2 \\
5 & 20 & 2,5 \\
6 & 24 & 3 \\
7 & 28 & 3,5 \\
8 & 32 & 4 \\
9 & 36 & 4,5 \\
10 & 40 & 5 \\
\hline
\end{tabular}


According to Table 3.2 above it is known that load cell output voltage in a state of maximum has a burden of 40 $\mathrm{mV}$. To adjust the microcontroller ADC voltage range between 0-5 volts, then the instrument amplifier gain of the circuit is set at 125 .

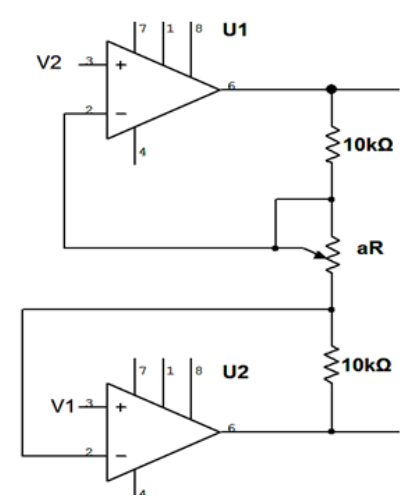

Figure 3.3. Amplifier Instrument

As shown in Figure 3.3 can be known instrument amplifier output is $V_{o}=\left(V_{2}-V_{1}\right)(1+2 R / a R)$. Where the gain is $(1+2 R / a R)$, aR is a potentiometer that is used to set the desired gain value. If the $\mathrm{R}$ value which is selected by $10 \mathrm{Kohm}$, then: $1+2 R / a R=125$

$a R \cong 161$

So to get the value of a gain of 125 , then the aR must be adjusted to $161 \mathrm{Ohm}$. The output signal from the instrument amplifier circuit is then entered in the differential amplifier circuit, as shown in Figure 3.4.

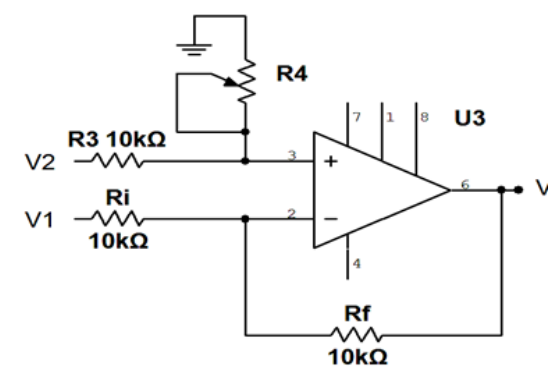

Figure 3.4. Differential amplifier

The differential amplifier circuit serves to locate the voltage difference between V1 and V2 which differenciate to the ground. Potentiometer in the Figure 3.4 that serves as a counterweight series. It can be seen that

$$
\begin{aligned}
& V o=\left(\left(\frac{R f}{R i}+1\right)\left(\frac{R 2}{R 1+R 2}\right) 2\right)\left(\frac{R f}{R i} V 1\right) \text { Where } \mathrm{Rf}=\mathrm{Ri}=\mathrm{R} 2=\mathrm{R} 1=\mathrm{R}, \quad \text { then the result is, } \\
& V_{o}=\left(\left(\frac{10}{10}+1\right)\left(\frac{10}{10+10}\right) V^{2}\right)\left(\frac{10}{10} V 1\right) V o=V 2=V 1
\end{aligned}
$$




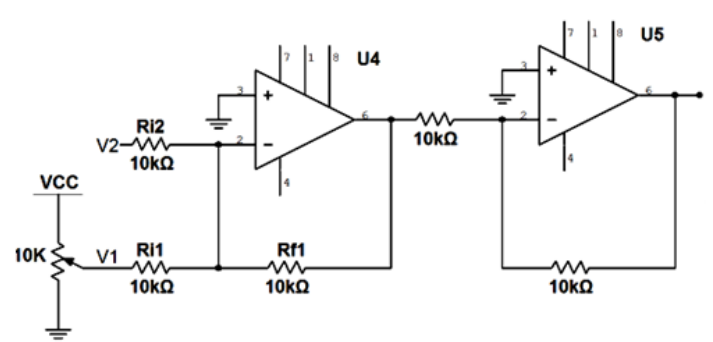

Figure 3.5. Inverting adder

Inverting adder circuit serves as input adder as shown in Figure 3.5. In this case inverting adder works as a circuit calibration (to reduce or decrease the initial load contained on conveyor belt). By changing the value of the potentiometer contained in inverting adder circuit, the load will start from zero.

\subsection{Tachometer}

The discs on this tachometer diameter are $2.6 \mathrm{~cm}$, so can be determined the circumference by using the formula of circumference of a circle, namely:

$$
\begin{gathered}
\text { Circumference }=2 \pi r=\pi D \\
=3,14 \times 2,6 \mathrm{~cm} \\
=8,164 \mathrm{~cm}
\end{gathered}
$$

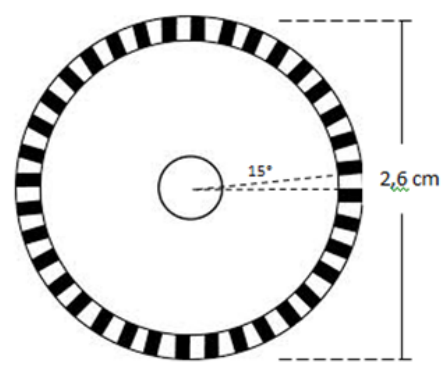

Figure 3.6. Tachometer disc

As illustrated in Figure 3.6, tachometer discs consisting of 24 holes, with a $15^{\circ}$ angular distance between holes. Therefore, when the disc rotates one full rotation ( 24 holes) it is equal to move as far as $8.164 \mathrm{~cm}$. By knowing the circumference of this disc, the conveyor belt speed can calculate the comparison between distance with time. This calculation is performed at the speedo coding contained in the microcontroller program.

Here is exemplified when a rotating conveyor belt can detect the rotation of the tachometer as much as half a round $(12$ holes $=4.082 \mathrm{~cm})$ in one second, the speed of the conveyor belt are:

$$
\begin{array}{r}
v=\frac{s}{t} \\
v=\frac{4,082}{1} \\
v=4,082 \mathrm{~cm} / \mathrm{sec}
\end{array}
$$

\subsection{Motor Driver}

The motor driver as an actuator regulates the supply voltage DC motor so that the speed can be controlled is shown in Figure 3.7. This circuit receives the PWM signal from the microcontroller via optocoupler. This optocoupler will distribute a variable voltage on the gate of MOSFET so that the current $\mathrm{I}_{\mathrm{DS}}$ changes in their work area. Optocoupler also serves as an insulator to secure microcontroller. 


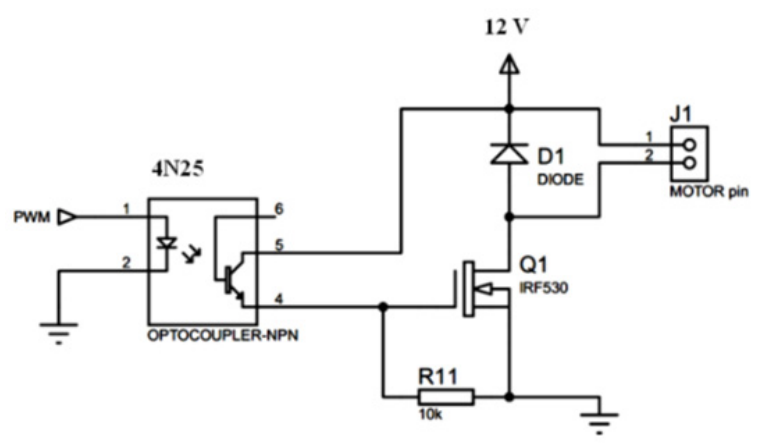

Figure 3.7. Motor Driver

\subsection{Visual Basic Program 2010}

Algorithm programming in Visual Basic 2010 are as follows:

a) Configuration Setting and connect to serial port.

b) Enter the value of set-point flow rate.

c) Send the "v" protocol to activate PWM.

d) Send the set-point value.

e) Activate timer.

f) Send the "x" protocol for PV data.

g) Read the PV data and display.

h) Send the "y" protocol for MV data.

i) Read MV data and display.

j) Send the "w" protocol to stop PWM.

\subsection{FIS Design}

By seeing to flow rate reference value in 1000 and 2000 grams / minute, it can be estimated that dynamics of the process that will occur in each of the variables; (E) and (CE) in the range of [-2000 2000]; and (U) in the range of $[-2020]$. Wherein $(\mathrm{E})$ is the difference between the set-point with the reading of the flow rate, and (U) is the amount of compensation for the value of PWM.

There are 81 variable compositions to be used as training data are entered on the ANFIS which are entered in the editor ANFIS Matlab toolbox in order to know the target output in Figure 3.8.

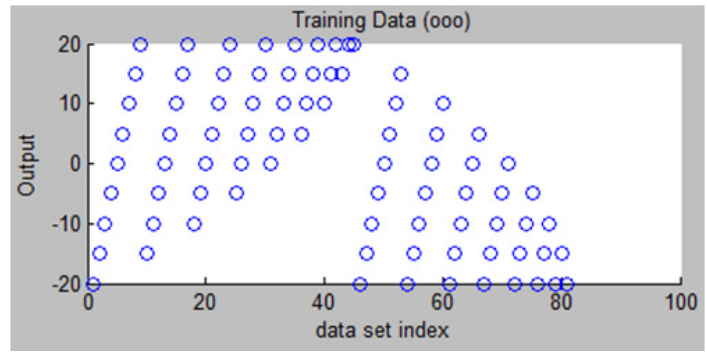

Figure 3.8. Plot training data of ANFIS

Through the configuration process of FIS generates which are entered in the editor toolbox matlab generated plots membership function of input variables $\mathrm{E}$ and $\mathrm{CE}$ as in Figure 3.9 and Figure 3.10. 


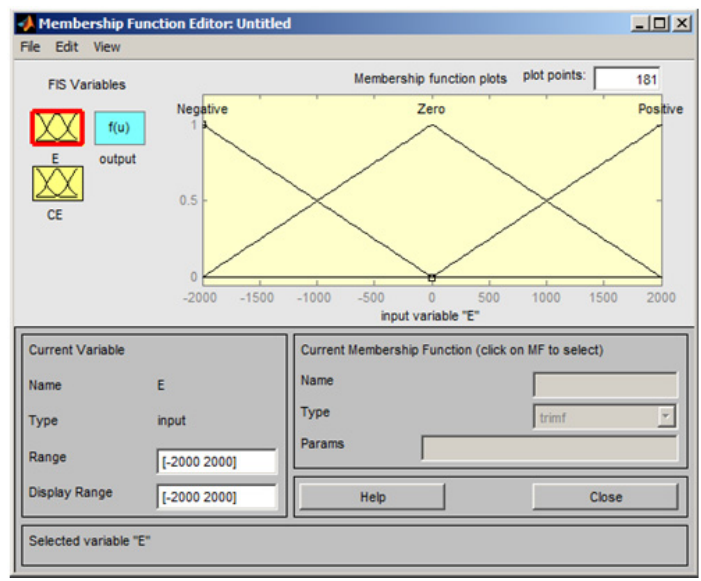

Figure 3.9. Plot membership function of E Variable

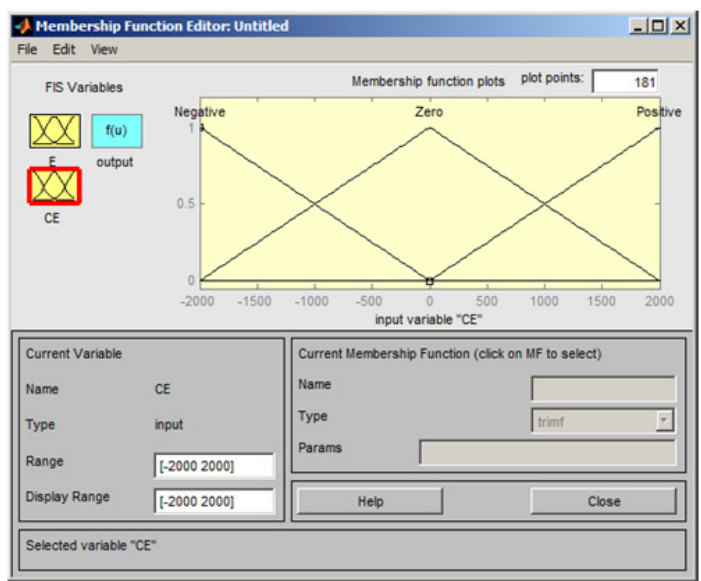

Figure 3.10. Plot membership function of CE Variable

It is known according to the Figure 3.9 and Figure 3.10 that, the type of membership function negative, zero, and positive use trimf.

From the training process based on the data input / output with error tolerance of 0.0001 and epoch in 1000 resulted in the training error of 2,4227e-06. In the form of graphs it can be seen from the plot the training error in the Figure 3.11.

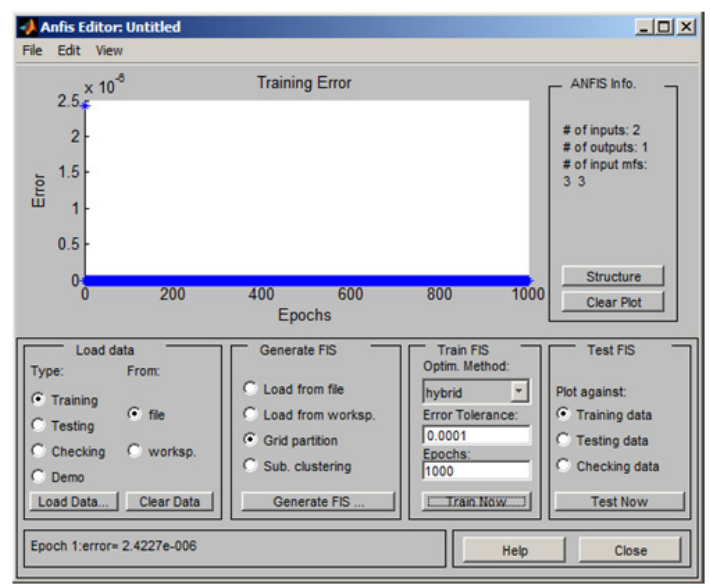

Figure 3.11. Training Error Plot

ANFIS training process based on the data input / output to produce an adaptation of the parameters of the MF 
and 9 fuzzy rules with the parameters in Table 3.3 and 3.4 as follows:

Table 3.3. FIS input Parameter

\begin{tabular}{lllll}
\hline $\begin{array}{l}\text { Variabe } \\
\text { l Input }\end{array}$ & Himpuna & \multicolumn{3}{l}{ Parameter anteseden } \\
n fuzzy & a & b & c \\
\hline E & Negative & -4000 & -2000 & 0 \\
& Zero & -2000 & 0 & 200 \\
& & & & 0 \\
& Positive & 0 & 2000 & 400 \\
& & & & 0 \\
CE & Negative & -4000 & -2000 & 0 \\
& Zero & -2000 & 0 & 200 \\
& & & & 0 \\
& Positive & 0 & 2000 & 400 \\
& & & & 0 \\
\hline
\end{tabular}

By choosing the constant output type then it will obtain consequent parameters as shown in Table 3.4.

Table 3.4. FIS output parameters

\begin{tabular}{ll}
\hline Rule No. & k \\
\hline 1 & -20 \\
2 & -20 \\
3 & -20 \\
4 & $-1,521 \mathrm{e}-011$ \\
5 & $6,471 \mathrm{e}-012$ \\
6 & $-5,987 \mathrm{e}-013$ \\
7 & 20 \\
8 & 20 \\
9 & 20 \\
\hline
\end{tabular}

\subsection{Microcontroller Program}

In the process of data transmission between notebook and microcontrollers, communication parameters need to be adjusted to each other. Communication protocol that is sent from the notebook is received by the microcontroller on the register UDR. The structure of data transmission to the source code is as follows:

while(UCSRA.7) //Waiting for new data

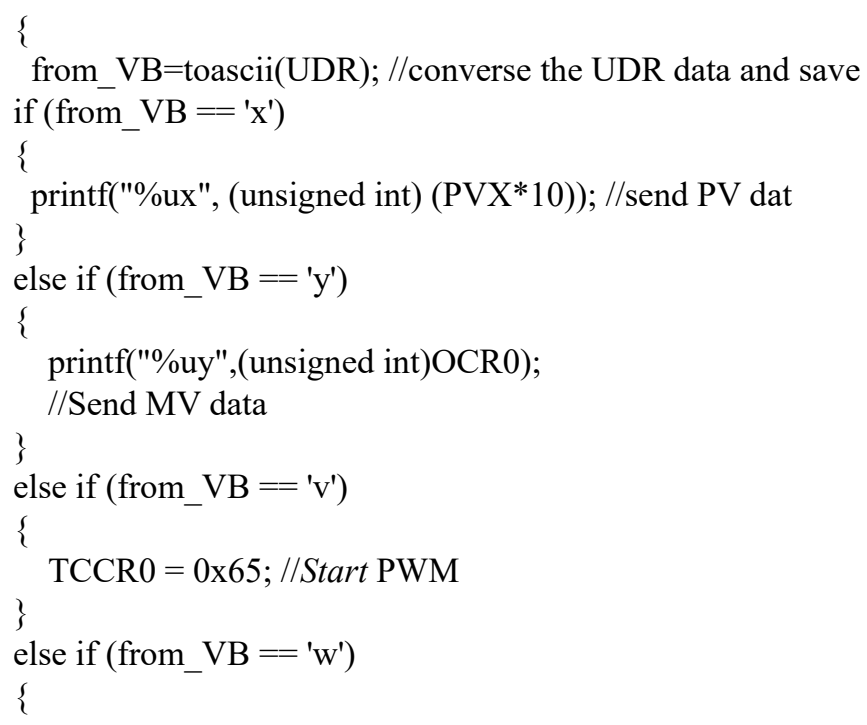




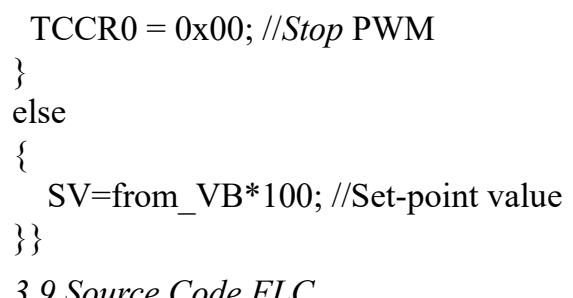

The parameters of input / output of FIS are applied to some function block programming. Source codes in basic language are created through software Visual Basic 2010 is as follows: Private Sub inputl () 'a representation of the membership function

If $\mathrm{i}<=$ a1 Then

$$
\operatorname{alpA}=0
$$

ElseIf $\mathrm{i}>=$ a1 And $\mathrm{i}<=\mathrm{b} 1$ Then

$$
\text { alpA }=(\mathrm{i}-\mathrm{a} 1) /(\mathrm{b} 1 \text { - a1) }
$$

ElseIf $\mathrm{i}>=\mathrm{b} 1$ And $\mathrm{i}<=\mathrm{c} 1$ Then

$$
\operatorname{alpA}=(c 1-i) /(c 1-b 1)
$$

ElseIf $\mathrm{i}>\mathrm{c} 1$ Then

$$
\text { alpA }=0
$$

End If

End Sub

\section{Data Testing and Analysis}

\subsection{Weighing Function Tests}

According to the value of ADC data it can be determined the value of $\mathrm{x}$ which is ADC value in the range of (25-109), and $y$ is the weighing value in the range of (0-300), so we can get the linier equation for $y=3,5714 x-$

\begin{tabular}{|c|c|c|c|c|}
\hline $\begin{array}{l}\text { Static } \\
\text { (gram) }\end{array}$ & Weigh & ADC & $\begin{array}{l}\text { Reading of } \\
\text { weigh(gram) }\end{array}$ & $\begin{array}{l}\text { Error } \\
(\%)\end{array}$ \\
\hline 0 & & 25 & 0,00 & 0,00 \\
\hline 50 & & 38 & 46,43 & 7,145 \\
\hline 100 & & 57 & 99,99 & 0,002 \\
\hline 150 & & 65 & 142,86 & 4,76 \\
\hline 200 & & 81 & 192,94 & 3,53 \\
\hline 250 & & 91 & 235,80 & 5,68 \\
\hline 300 & & 109 & 300,08 & 0,03 \\
\hline \multicolumn{4}{|l|}{ Aver } & 3,021 \\
\hline
\end{tabular}
89,2857 . This equation will later be implemented in the source code of ADC to get the weighing variable value validity such as in the Table 4.1.

Table 4.1. Weighing Variable Validity

\subsection{Belt Conveyor Speed Function Testing}

\begin{tabular}{|c|c|c|c|c|}
\hline & $\begin{array}{l}\text { PWM } \\
\text { (10) }\end{array}$ & $\begin{array}{l}\text { PWM } \\
(15)\end{array}$ & $\begin{array}{l}\text { PWM } \\
\text { (20) }\end{array}$ & $\begin{array}{l}\text { PWM } \\
\text { (25) }\end{array}$ \\
\hline Speed & 0,34 & 1,02 & 3,4 & 4,76 \\
\hline belt & 0,34 & 1,7 & 3,4 & 4,76 \\
\hline
\end{tabular}

Speed function testing give some variation the value of PWM in 10 times taking obtained from the data in the Table 4.2.

Table 4.2. Belt conveyor speed data testing 


\begin{tabular}{lllll}
\hline conveyor & 0,34 & 1,36 & 3,4 & 4,42 \\
$(\mathrm{~cm} / \mathrm{sec})$ & 0,68 & 1,7 & 3,74 & 5,1 \\
& 0,34 & 2,04 & 3,4 & 4,76 \\
& 0,34 & 1,7 & 3,4 & 4,76 \\
& 0,34 & 2,04 & 3,74 & 5,1 \\
& 0,34 & 1,7 & 3,4 & 4,76 \\
& 0,34 & 2,04 & 3,4 & 5,1 \\
& 0,68 & 1,7 & 3,4 & 4,76 \\
\hline
\end{tabular}

\subsection{Validation of Flow Rate}

Validation of the flow rate is intended to determine the function of flow rate values calculated based on a constant load and speed. Flow rate value is obtained by using the formula :

$$
\mathrm{I}=\mathrm{Q} * \mathrm{~V}
$$

With I : Flow rate $(\mathrm{kg} / \mathrm{s})$

$$
\begin{aligned}
& \mathrm{Q}: \text { Belt load }(\mathrm{kg} / \mathrm{m}) \\
& \mathrm{V}: \text { Belt speed }(\mathrm{m} / \mathrm{s})
\end{aligned}
$$

By providing a static load of 200 grams and a PWM value of 20, then it will obtain logging data of flow rate for one minute as it shown in the following chart in Figure 4.1.

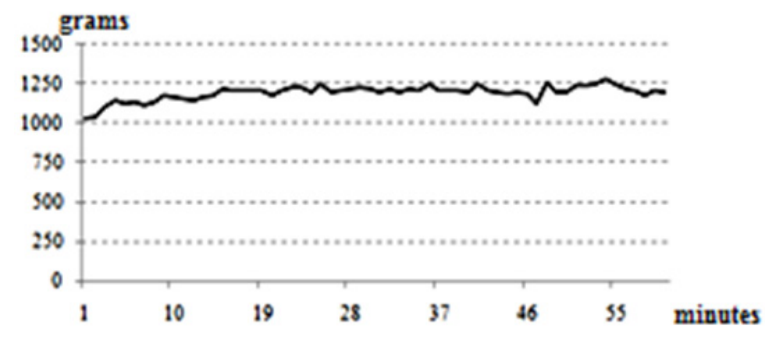

Figure 4.1. Flow rate validation

From the logging data obtained through a validation process for one minute can be calculated the flow rate value of the average - average which is 1193.4 grams / minute.

\subsection{ANFIS Testing}

ANFIS testing has an aim to get the training error tolerant value at the maximum of 0.0001 in 3000 times training epoch. This ANFIS testing is done based on the training data composition and FIS configuration.

By seeing to the flow rate reference value of 1000 and 2000 grams / minute, it can be estimated that dynamics of the process are will occur in each of the variables; (E) and (CE) in the range of [-2000 2000]; and $U$ in the range of [-20 20].

From the experimental results of FIS configuration it is known the value of the smallest training error is $2,4227 \mathrm{e}-06$. Training error value is derived from the type of membership function and an output triangle with the number of inputs to the first epoch of $3 \times 3$.

Antecedent parameter values obtained in the input variables $\mathrm{E}$ and $\mathrm{CE}$ as in the Table 4.3.

Table 4.3 FIS input Parameter

\begin{tabular}{lllll}
\hline \multirow{2}{*}{ Input Variable } & Fuzzy Set & \multicolumn{4}{c}{ Antecedent Parameter } \\
& a & b & c \\
E & Negative & -4000 & -2000 & 0 \\
& Zero & -2000 & 0 & 2000 \\
\hline
\end{tabular}




\begin{tabular}{lllll}
\hline & Positive & 0 & 2000 & 4000 \\
& Negative & -4000 & -2000 & 0 \\
CE & Zero & -2000 & 0 & 2000 \\
& Positive & 0 & 2000 & 4000 \\
\hline
\end{tabular}

From the nine rules obtained we can get consequent parameter value on the output variables which are presented in Table 4.4.

Table 4.4. FIS output Parameter

\begin{tabular}{ll}
\hline Aturan ke- & $\mathbf{k}$ \\
\hline 1 & -20 \\
2 & -20 \\
3 & -20 \\
4 & $-1,521 \mathrm{e}-011$ \\
5 & $6,471 \mathrm{e}-012$ \\
6 & $-5,987 \mathrm{e}-013$ \\
7 & 20 \\
8 & 20 \\
9 & 20 \\
\hline
\end{tabular}

\subsection{FLC Testing}

FLC testing give reference value/set-point in the amount of $1000 \mathrm{gr} /$ minute and $2000 \mathrm{gr} /$ minute. The first testing on the set-point of $1000 \mathrm{gr} /$ minute we can get trending flow rate and FLC output as shown in Figure 4.1.

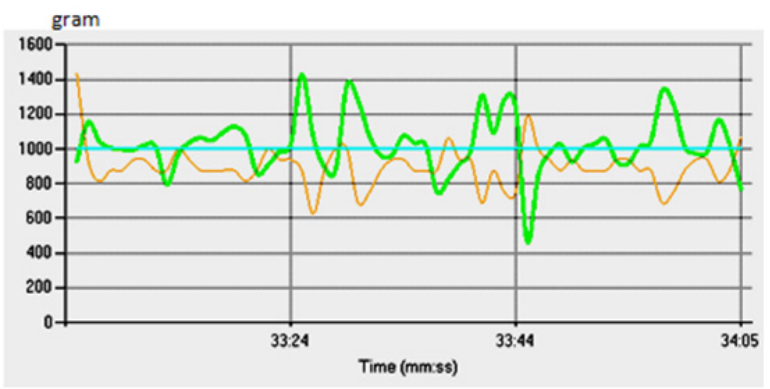

Figure 4.1. Trending on set-point of $1000 \mathrm{gr} / \mathrm{mnt}$

By doing several times of testing on the set point of $1000 \mathrm{gr} / \mathrm{min}$ we can get the total result of weighing every one minute as in Table 4.4.

Table 4.4. Total Weighing per minute on the set point of $1000 \mathrm{gr} / \mathrm{min}$

\begin{tabular}{ccc}
\hline Test & Total Weight (gram) & Error (\%) \\
\hline 1 & 1023 & 2.3 \\
2 & 1055 & 5.5 \\
3 & 1012 & 1.2 \\
4 & 1034 & 3.4 \\
5 & 1029 & 2.9 \\
6 & 1072 & 7.2 \\
7 & 1017 & 1.7 \\
8 & 1042 & 4.2 \\
9 & 1038 & 3.8 \\
10 & 1064 & 6.4 \\
\multicolumn{2}{c}{ Average Error $\mathbf{( \% )}$} & 3.86 \\
\hline
\end{tabular}


Testing on the set-point of $2000 \mathrm{gr} / \mathrm{min}$ will get trending flow rate and FLC output as shown in Figure 4.2.

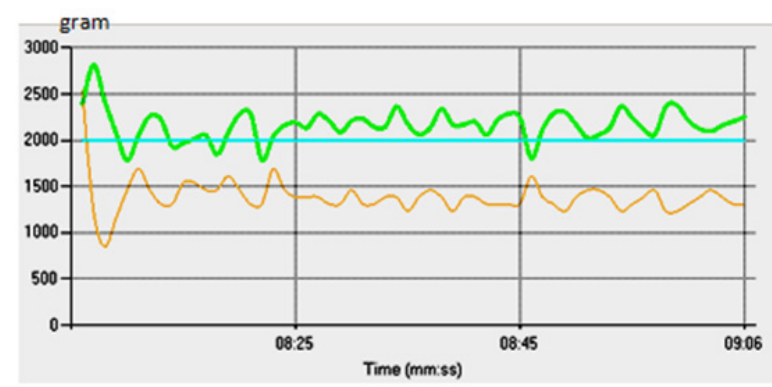

Figure 4.2. Trending on the set-point of $2000 \mathrm{gr} / \mathrm{min}$

Tests on set-point in $2000 \mathrm{gr} / \mathrm{min}$ showed total weighing every one minute as in Table 4.5.

Table 4.5. Total weighing per minute on the set-point of $2000 \mathrm{gr} / \mathrm{min}$

\begin{tabular}{lll}
\hline Test & Total Wight (gram) & Error $\mathbf{( \% )}$ \\
\hline 1 & 2098 & 4.9 \\
2 & 2105 & 5.25 \\
3 & 2096 & 4.8 \\
4 & 2101 & 5.05 \\
5 & 2094 & 4.7 \\
6 & 2108 & 5.4 \\
7 & 2113 & 5.65 \\
8 & 2087 & 4.35 \\
9 & 2095 & 4.75 \\
10 & 2109 & 5.45 \\
Average Error $\mathbf{( \% )}$ & 5.03 \\
\hline
\end{tabular}

From the FLC testing based on the given set point has total weighing error in every minute. On the set point of $1000 \mathrm{gr} / \mathrm{min}$ has average errors of $3,86 \%$ and for the set point of $2000 \mathrm{gr} / \mathrm{min}$ has an average errors of 5,03\% The existence of those errors are caused by the dynamics of fluctuate flow rate and the response if FLC.

This study is actually to support previous results focusing on Neuro-Fuzzy in renewable energies (Garcia, 2014), health monitoring (Agrawal, 2013), developing model (Bisht, 2011), information security (Altaher, 2012), edge detection technique (Bhardwaj, 2013), temperature and humadity system (Ramesh, 2015). Other advantages of the fuzzy can also be found on automatic RNA virus classification (Dogantekin, 2013), and predicting the volumes of Chaotic Traffic (Yeh, 2012).

In sort, ANFIS (Adaptive Neuro-Fuzzy Inference System) is quiet prominant to sustain technology advancements and develop better advantages.

\section{Conclusion}

\subsection{Conclusion}

From the activities of the final of the task that has been done can be taken some conclusions as follows:

1. Validation of the flow rate can indicate a dynamic flow rate which can be used as reference data in determining the composition of the process variables to design FLC controllers using ANFIS.

2. ANFIS testing based on the data composition training has fulfilled the error tolerant limit so that we can form FIS design programmed based on the research results parameter.

3. FIS design implementation into the visual basic programming 2010 has a valid output value compared to the editor of ANFIS rule viewer. Those out values represent FLC validity which is programmed in microcontroller.

4. ANFIS can make it easier to determine the design parameters of FIS, so that the performance of the 
controller can be adjusted based on the conditions of plant dynamics.

5. Overall the flow rate control system in weight feeder conveyor is working in accordance with the principle of close loop control, where the FLC controller is able to control the flow rate with total sampling results of weighing for one minute which is considered as good. Their error total weighing and oscillating flow rate is more influenced by the mechanical construction of the conveyor belt as well as friction or dynamic loads.

\subsection{Suggestion}

For more improvement and fixing the performance of the system that has been created it is then necessary to recommend:

Composition ANFIS training data can be augmented by sampling data from the dynamics of the process of flow rate directly to enhance the performance of the controller of FLC.

FIS configuration can be customized further by modifying the number and type of membership function and the type of output to generate value with smaller training error.

The stability of control process of flow rate in weight feeder conveyor can be increased based on the type or types of controllers which are better, for example by using artificial intelligent-based controllers or online neuro fuzzy.

\section{References}

Agrawal, A. T., \& Ashtankar, P. S. (2013). Adaptive Neuro-Fuzzy Inference System for Health Monitoring at Home. International Journal of Advanced Science and Technology, 55.

Altaher, A., Almomani, A., \& Ramadass, S. (2012). Application of Adaptive Neuro-Fuzzy Inference System for Information Secuirty. Journal of Computer Science, 8(6), 983-986, 2012 ISSN 1549-3636. (C) 2012 Science Publications.

Bhardwaj, K., \& Mann, P. S. (2013). Adaptive Neuro-fuzzy Inference System (ANFIS) Based Edge Detection Technique. International Journal for Science and Energing Technologies with Latest Trends, 8, 7-13.

Bisht, D., \& Jangid, C. S. (2011). Discharge Modelling using Adaptive Neuro - Fuzzy Inference System. International Journal of Advanced Science and Technology, 31.

Dogantekin, E., Avci, E., \& Erkus, O. (2013). Automotic RNA Virus Classification using the Entropy-ANFIS Method. Digital Signal Processing. Elsevier, 23(4), 1209-1215.

Garcia, P., Garcia, C. A., Fernandez, L. M., \& Llorens, F. (2014). ANFIS Based Control of a Grid-Connected Hybrid System Integrating Renewable Energies, Hydrogen and Batteries. IEEE Transactions on Industrial Informatics, 10(2), 1107-1117.

Kusumadewi, S. (2006). Neuro - Fuzzy Integrasi Sistem Fuzzy dan Jaringan Syaraf, Graha Ilmu, Jakarta.

Nazaruddin, Y. Y., dan Meiriansyah, A., \& Pengontrol, P. I. (2009). Swatala Berbasis Neuro - Fuzzy, Skripsi, Kelompok Keahlian Instrumentasi dan Kontrol - Program Studi Teknik Fisika ITB, Bandung.

Ramesh, K. A., Kesarkar, P., Bhate, J., Ratnam, M. V., \& Jayaraman, A. (2015). Adaptive neuro-fuzzy inference system for temperature and humidity profile retrieval from microwave radiometer observations. Atmos. Meas. Tech., 8, 369-384.

Saputro, C. A. (2007). Kendali Self Tuning Fuzzy PI Pada Pengendalian Weight Feeder Conveyor, Skripsi, Jurusan Teknik Elektro Fakultas Teknik Universitas Diponegoro, Semarang.

Widodo, S., T. (2005), Sistem, Neuro Fuzzy, Graha Ilmu, Yogyakarta.

Yeh, J. P., \& Chang, Y. C. (2012). Comparison between Neural Network and Adaptive Neuro-Fuzzy Inference System for Forecasting Chaotic Traffic Volumes. Journal of Intelligent Learning Systems and Applications, 2012(4), 247-254

\section{Copyrights}

Copyright for this article is retained by the author(s), with first publication rights granted to the journal.

This is an open-access article distributed under the terms and conditions of the Creative Commons Attribution license (http://creativecommons.org/licenses/by/3.0/). 